\title{
Effect of phytoplankton and temperature on the reproduction of the Pacific oyster Crassostrea gigas: Investigation through DEB theory
}

\author{
I. Bernard ${ }^{a, b}$, G. de Kermoysan ${ }^{a}$, S. Pouvreau ${ }^{a, *}$ \\ a IFREMER, PFOM/PI, 11 presqu'île du vivier, 29840 Landunvez, France \\ ${ }^{b}$ IFREMER, LER/PC, mus de loup, 17390 La Tremblade, France \\ *: Corresponding author : Stéphane Pouvreau, email address : Stephane.Pouvreau@ifremer.fr
}

\begin{abstract}
:
DEB theory can be used to obtain a detailed description of energy allocation in organisms and the control of this allocation by temperature and food concentration. In this study, we modified the model of Bourlès et al. (2009) developed for the Pacific oyster, Crassostrea gigas, to improve the description of reproductive effort. The model was amended in two ways: a new set of parameters was incorporated and a full description of gonad construction in spring was added, with a new state variable. The application of this model to a dataset for oyster growth measured in four bays over two years showed that this model better described reproductive effort, without modifying overall growth dynamics. We then explored the reproductive responses of oysters to their environment in greater detail, by applying this new version of the model with the theoretical forcing variables of phytoplankton concentration and temperature. Spawning time was found to be driving principally by yearly mean temperature, and reproductive effort was found to depend mostly on the half-saturation coefficient of the functional response. These results highlight the importance of the half-saturation coefficient and provide additional support for field research on the food preferences of oysters.
\end{abstract}

\section{Highlights}

We developed an improved version of the DEB model for Pacific oyster, C. gigas. This model is used to give a deep insight into the ecophysiology of reproduction and the ecology of this species. It gives another utilization of the DEB theory as a tool to better understand ecology processes.

Keywords: DEB model ; Crassostrea gigas ; Gametogenesis ; Reproductive effort ; Spawning date ; Functional response

\section{Introduction}

The link between larval stage and subsequent population dynamics, known as supply-side ecology (Underwood and Fairweather, 1989; Grosberg and Levitan, 1992), has been investigated in detail, in studies of the recruitment of marine benthic invertebrates. The relationship between the supply of oocytes from adults and the abundance of larvae for subsequent recruitment has been investigated less thoroughly, and much remains unclear, particularly for bivalves (MacKenzie, 1996; Marshall et al., 2009). The principal reason for this may be the di_culties involved in simultaneously obtaining data for stock size, fecundity - defined as the number of eggs produced per individual - and recruitment over a long time period or a broad geographical range. 
Although conclusive studies are lacking, some previous work stresses the fact that oocyte supply may, under certain conditions, influence subsequent recruitment. For corals, Hughes et al. (2000) found a link between spatial fecundity and recruitment, defined in this study as the percentage of colonies with ripe oocytes. For the blue crab, links between spawning stock and larval abundance and between spawning stock and recruitment were shown by Lipcius and Stockhausen (2002). In studies on bivalves, Honkoop et al. (1998) found no link between fecundity and recruitment for Macoma balthica, but did report a relationship between winter temperature and subsequent recruitment. Using stock size, Kraeuter et al. (2005) showed a stock recruitment relationship at low stock densities for Mya arenaria. There may thus be a link between oocyte supply and subsequent recruitment, but available studies do not allow us to derive a general pattern.

In Pacific oyster, variability in reproductive effort has already been proposed as a possible reason for recruitment variability (Deslous-Paoli et al., 1982). The authors of this previous study suggested that unfavourable food and temperature conditions might lead to abnormal gametogenesis and delayed spawning. Temperature is, effectively, an important driver of gametogenesis in $C$. gigas populations. A minimum temperature seems necessary to initiate gametogenesis (Chavez-Villalba et al., 2002a; Fabioux et al., 2005). Temperature also influences the speed of gamete development, making day degrees a useful measure to indicate when oysters in hatcheries are ripe (Mann, 1979). Once gametogenesis is complete, there is a minimum temperature requirement for spawning. Castaños et al. (2009) estimated this minimum temperature threshold at $17^{\circ} \mathrm{C}$. Pouvreau et al. (2006) used $20^{\circ} \mathrm{C}$ in their model, but many other studies have been carried out and have given different values.

Food availability is thought to regulate the number of gametes produced (Chavez-Villalba et al., 2002b) and Auby and Maurer (2004) found a positive correlation between the condition index of $C$. gigas oysters before spawning, reflecting fecundity, and mean chlorophyll $a$ concentration in spring. They also found that this condition index was related to larval supply, suggesting that fecundity may play a role in larval supply. However, feeding is not always necessary for the completion of gametogenesis, which may instead depend on prior storage (Muranaka and Lannan, 1984; Cannuel and Beninger, 2005). The fact that oysters with large energy reserves at the start of gametogenesis ripen before oysters with smaller reserves (Chavez-Villalba et al., $2002 \mathrm{~b}$ ), indicates an important contribution of feeding conditions before gametogenesis.

These studies suggest that the quantification of both temperature and food availability is required to describe the energetic pathway leading to gametogenesis in the Pacific oyster. Biochemical studies have already provided insight into this pathway (Deslous-Paoli and Héral, 1988). These authors showed that $C$. gigas lost up to $70 \%$ of its energy during spawning. DEB theory, based on a multi-specific and axiomatic approach (Sousa et al., 2008; Kooijman, 2010), provides a general description of energy allocation based on these two forcing variables (temperature and food). Several studies have already been carried out on Pacific oysters have built the parameter set for this species (Ren and Ross, 2001; van der Veer et al., 2006), which has been tested in various environments (Pouvreau et al., 2006; Bacher and Gangnery, 2006; Bourlès et al., 2009; Alunno-Bruscia et al., 2011, this issue).

Following on from previous work on the oyster DEB model, the objective of this study was to focus on the influence of both food and temperature on reproductive effort and spawning. More precisely, we wanted to quantify how reproductive effort - in terms of the number of gametes produced - and spawning date could be altered by forcing variables. In order to validate the oyster DEB model over a wide range of phytoplankton concentrations and temperatures, we used datasets for four sites along a latitudinal gradient corresponding to the French Atlantic coast, in 
2008 and 2009. We used phytoplankton concentration as a proxy for food, because it has been shown to describe oyster growth more precisely than chlorophyll-a concentration (Bourlès et al., 2009).

To improve simulation, we modified the original version of the $C$. gigas DEB model published by Bourlès et al. (2009). We altered the model to improve its description of the observed reproductive effort, in terms of dry flesh mass, for all sites and years, by changing the values of several parameters and adding a new state variable for the specific description of gonad allocation. For each site and each year, the new model reproduced the observed reproductive effort more accurately than the previous model. At the end of this paper, we provide a theoretical description of the variation of reproductive effort as a function of temperature and phytoplankton concentration, based on this improved model of energy allocation in oyster.

\section{Model and data}

\subsection{Standard DEB model}

The model used here is derived from the standard DEB model presented by Kooijman (2010). A detailed description of the initial model for Pacific oyster can be found in Pouvreau et al. (2006) and a modified version can be found in Bourlès et al. (2009). We therefore provide only a brief overview of this model here. It uses three energetic state variables expressed in joules: the energy stored in reserves, $E$, the energy used in the building of the structure, $E_{V}$, and the energy used for reproduction, $E_{R}$. The energy used in the construction of structure relates to a volume using the volumetric cost of structure construction, $\left[E_{G}\right]$. Volume can then be related to length, $L$, through the shape parameter, $\delta_{M}$, and the relationship $V=\left(\delta_{M} L\right)^{3}$.

Most fluxes are also identical to those of the model presented by Pouvreau et al. (2006) and Bourlès et al. (2009), see table 1. All fluxes are formulated in ${\mathrm{J} . \mathrm{d}^{-1}}^{-1}$ The values of the corresponding parameters used here were mostly obtained from van der Veer et al. (2006), Pouvreau et al. (2006), Bourlès et al. (2009) and other studies (Tab. 2). Their signification follows their definition by Kooijman (2010).

\begin{tabular}{l|l|l}
\hline Name of the flux & & Formula \\
\hline Assimilation & $\dot{p}_{A}$ & $=t_{i m}\left\{\dot{p}_{A m}\right\} f V^{2 / 3}$ \\
Catabolic utilisation & $\dot{p}_{C 1}$ & $=\frac{E}{\left[E_{G}\right]+\kappa E / V}\left(\frac{\left[E_{G}\right]\left\{\dot{p}_{A m}\right\}}{\left[E_{m}\right] V^{1 / 3}}+\left[\dot{p}_{M}\right]\right)$ \\
Growth & $\dot{p}_{G}$ & $=\kappa \dot{p}_{C 1}-\dot{p}_{M 1}$ \\
Reproduction & $\dot{p}_{R}$ & $=(1-\kappa) \dot{p}_{C 1}-\dot{p}_{J}$ \\
Somatic maintenance & $\dot{p}_{M 1}$ & $=\left[\dot{p}_{M}\right] V$ \\
Maturity maintenance & $\dot{p}_{J}$ & $=\frac{1-\kappa}{\kappa} \min \left(V, V_{p}\right)\left[\dot{p}_{M}\right]$ \\
Gamete mobilization* & $\dot{p}_{C 2}$ & $=E_{R}\left(\frac{\left\{\dot{p}_{A m}\right\}}{\left[E_{m}\right] V^{1 / 3}}+\frac{\left[\dot{p}_{M}\right]}{\left[E_{G}\right]}\right)\left(1-\kappa \frac{E}{\left[E_{G}\right] V+\kappa E}\right)$ \\
Emergency maintenance & $\dot{p}_{M 2}$ & $=\min \left(\dot{p}_{M 1}-\kappa \dot{p}_{C 1}, \dot{p}_{C 2}\right)$ \\
Gonad allocation* & $\dot{p}_{G o}$ & $=\dot{p}_{C 2}-\dot{p}_{M 2}$ \\
Lysis of structure* & $\dot{p}_{L 1}$ & $=\max \left(\dot{p}_{M 1}-\left(\kappa \dot{p}_{C 1}+\dot{p}_{M 2}+\dot{p}_{L 2}\right), 0\right)$ \\
Resorption of gonad & $\dot{p}_{L 2}$ & $=\max \left(\left(\dot{p}_{M 1}-\left(\kappa \dot{p}_{C 1}+\dot{p}_{M 2}\right)\right) / Y_{G o}, 0\right)$ \\
\hline
\end{tabular}

Table 1: Detail of all fluxes used in the complete model. * Denotes new fluxes defined in this study.

Size, represented here by $E_{V}$, is a key state variable in the DEB model and is subject to specific assumptions. C. gigas oysters are assumed to be isomorphic, implying that their area 
increases in proportion to their volume. This relationship is important because size is used to determine both energy entering the organism and energy consumed by its body, represented by the assimilation flux, $\dot{p}_{A}$, and the maintenance flux $\dot{p}_{M 1}$, (formerly $\dot{p}_{M}$ ), respectively. Assimilation is proportional to the structural surface, $V^{2 / 3}$, and maintenance is directly proportional to volume (Tab. 1).

The standard DEB model does not specifically describe energy allocation to gonad. We modified this DEB model in two ways, to improve the description of reproduction-related features: (i) we added a full description of energy allocation to the gametogenesis and resorption processes and (ii) we changed some parameter values and defined new parameters.

\subsection{Gametogenesis state variable and fluxes}

We focused on improving the representation of reproductive processes by the DEB model for oyster, to make this model a useful tool for understanding and quantifying the energetics of reproduction. With the standard DEB model for oysters (Pouvreau et al., 2006; Bourlès et al., 2009), it was impossible to differentiate the gonad formation in the spring from the accumulation of energy reserves for reproduction in the autumn, so we added a new specific gonad compartment (Fig. 1), for three reasons. First, the ratio of dry flesh mass to wet flesh mass, referred to here as the mass ratio (MR), increased considerably in spring (Royer et al., 2008), in association with gametogenesis. Such high ratios were never reached in autumn, even if the oysters were fed ad libitum. Thus, the gonads and reproductive reserves are different in nature and make different contributions to dry flesh mass. Second, it may be harder for oysters to mobilize energy from the gonad constructed in spring than from the reproductive reserves amassed in autumn. Third, the yield from the mobilisation of reproductive reserves may greatly exceed the yield of gonad resorption, as nrevinuclv showen hy $I$ i at al (9nก) fio 1)

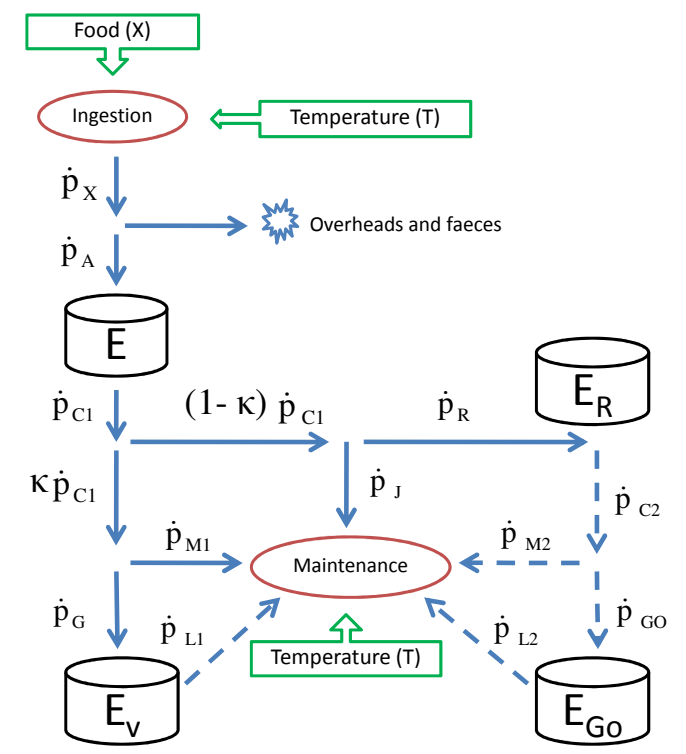

Figure 1: Schematic representation of physiological processes (ellipsoidal boxes), forcing variables (square boxes with an arrow), state variables (cylindrical boxes) and fluxes (arrows), with their mathematical names, in the new version of the DEB model used here. Continuous fluxes are represented by solid lines and temporary fluxes by dashed lines. 


\begin{tabular}{|c|c|c|c|c|}
\hline Symb. & Meaning & Value & Units & Origin \\
\hline \multicolumn{5}{|c|}{ Main parameters } \\
\hline$\delta_{M}$ & Shape parameter & 0.175 & - & van der Veer et al. 2006 \\
\hline$\left[\dot{p}_{M}\right]$ & Vol. specific maintenance cost & 44 & $J . \mathrm{cm}^{-3} \cdot d^{-1}$ & This study \\
\hline$\left[E_{G}\right]$ & Vol. specific cost for structure & 3900 & J.cm ${ }^{-3}$ & This study \\
\hline$\left[E_{m}\right]$ & Maximum storage density & 4200 & J.cm $\mathrm{cm}^{-3}$ & This study \\
\hline$\dot{v}$ & Energy conductance & 0.183 & cm. $d^{-1}$ & van der Veer et al. 2006 \\
\hline$\kappa$ & Fraction of $\dot{p}_{C 1}$ spent on growth & 0.45 & - & van der Veer et al. 2006 \\
\hline$\kappa_{X}$ & Assimilation efficiency & 0.75 & - & van der Veer et al. 2006 \\
\hline$L_{\infty}$ & Ultimate length & 45 & $\mathrm{~cm}$ & van der Veer et al. 2006 \\
\hline \multicolumn{5}{|c|}{ Additional parameters } \\
\hline$\mu_{E}$ & Energy content of reserves & 19600 & $J . g^{-1}$ & Kooijman 2010 \\
\hline$d_{V}$ & Dry mass ratio of structure & 0.15 & $g \cdot g^{-1}$ & Whyte et al. 1990 \\
\hline$d_{G o} *$ & Dry mass ratio of gonad & 0.31 & $g \cdot g^{-1}$ & Deslous-Paoli and Héral 1988 \\
\hline$\left[E_{G o}\right] *$ & Vol. specific cost for gonad & 7500 & J.8 $\mathrm{cm}^{-3}$ & This study \\
\hline$Y_{G o} *$ & Yield of gonad tissue used for maintenance & 0.25 & - & Li et al. 2009 \\
\hline$V_{p}$ & Structural vol. at puberty & 0.4 & $\mathrm{~cm}^{3}$ & Pouvreau et al. 2006 \\
\hline$t_{i m}$ & Percentage of immersion & 0.8 & - & Site data \\
\hline$G I$ & Gonado-somatic index triggering spawning & 46 & - & This study \\
\hline$T_{s}$ & Temperature threshold triggering spawning & 292 & $\mathrm{~K}$ & Pouvreau et al. 2006 \\
\hline \multicolumn{5}{|c|}{ Temperature effect } \\
\hline$T_{1}$ & Reference temp. for rates & 293 & $\mathrm{~K}$ & User Defined \\
\hline$T_{A}$ & Arrhenius temperature & 5800 & $\mathrm{~K}$ & van der Veer et al. 2006 \\
\hline$T_{L}$ & Lower boundary tolerance range & 281 & $\mathrm{~K}$ & Bourlès et al. 2009 \\
\hline$T_{\text {Hing. }}$ & Upper boundary tolerance range for ingestion process & 298 & $\mathrm{~K}$ & Bourlès et al. 2009 \\
\hline$T_{\text {Hmain }}$ & Upper boundary tolerance range for maintenance process & $\mathrm{K}$ & - & Bourlès et al. 2009 \\
\hline$T_{A L}$ & Arrhenius temp. for lower boundary & 75000 & $\mathrm{~K}$ & van der Veer et al. 2006 \\
\hline$T_{A H}$ & Arrhenius temp. for upper boundary & 30000 & $\mathrm{~K}$ & van der Veer et al. 2006 \\
\hline \multicolumn{5}{|c|}{ Feeding processes } \\
\hline $\begin{array}{c}X_{K} \\
\left\{\dot{p}_{A m}\right\}\end{array}$ & $\begin{array}{c}\text { Half-saturation coefficient } \\
\text { Surface specific max. assimilation rate }\end{array}$ & $\begin{array}{c}0.510^{6}-210^{6} \\
770\end{array}$ & $\begin{array}{l}\text { cells. } L^{-1} \\
\text { J.cm } \\
-2 \cdot d^{-1}\end{array}$ & $\begin{array}{c}\text { Calibration for each dataset } \\
\text { This study }\end{array}$ \\
\hline
\end{tabular}

Table 2: Parameters for the extended DEB model for $C$. gigas. $*$ Denotes new fluxes defined in this study. 
A fourth state variable, $E_{G O}$, was thus created to represent the energy used in the construction of the gonad, whereas $E_{R}$ describes the energy stored for reproduction. In spring and summer, an auxiliary catabolic flux, $\dot{p}_{C 2}$, is activated that uses the energy stored in $E_{R}$ to fill the gonad (Fig. 1). The formulation of this flux follows the same rules as those used for the main catabolic flux $\dot{p}_{C 1}$, see AppendixA.

Gonad construction is modelled similarly to the construction of structure. An optional maintenance flux, $\dot{p}_{M 2}$, takes priority over the flux of allocation to the gonad $\dot{p}_{G O}$. This optional maintenance flux is active only if the overall maintenance cost cannot be covered totally by the initial maintenance flux $\dot{p}_{M 1}$, i.e. if $e<L / L_{\infty}$. The last flux added, $\dot{p}_{L 2}$, relates to gonad resorption in cases of extreme starvation, e.g. when neither $\dot{p}_{M 1}$ nor $\dot{p}_{M 2}$ is sufficient to cover maintenance costs - with a yield of energy uptake from the gonad, $Y_{G o}$. In cases of extreme starvation with no gonad to resorb, the structure is lysed at a rate of $\dot{p}_{L 1}$, with a yield assumed to be equal to one, as a first approximation.

Chavez-Villalba et al. (2002a) showed that Pacific oysters begin to form gonads when the temperature rises in spring and stop when the temperature drops in autumn. Based on this observation, one simple way to model the initiation and termination of gonad construction is to fit a sinusoidal description of temperature: $a_{T} \sin \left(c_{T} t+d_{T}\right)+b_{T}$, where $a_{T}$ is half the yearly temperature amplitude, $c_{T}$ is the frequency of the signal $2 \pi / 365, d_{T}$ is the shift of the coldest period of the year and $b_{T}$ is yearly mean temperature. Date, $t$, is expressed in Julian days. Gonad construction begins when the derivative, $a_{T} c_{T} \cos \left(c_{T} t+d_{T}\right)$, exceeds 0 and stops when it becomes negative.

\subsection{Re-estimation of general parameters}

The Pacific oyster exhibits a high reproductive effort in terms of mass, and its gametes have a high energy content. Thus, reproductive effort after conversion into energy is greater than estimates based on mass ratio. It was impossible to generate such large amounts of mass with energetic values consistent with published data without changing the values of some parameters: including $\mu_{E},\left[E_{G}\right],\left\{\dot{p}_{A m}\right\}$ and $\left[\dot{p}_{M}\right]$ in particular.

In the previous version of the model (Bourlès et al., 2009), the chemical potential of reserves, $\mu_{E}$, in J.g $\mathrm{g}^{-1}$ of dry flesh mass was based on the Brody (1945) coefficient for glycogen, assuming that reserves consist mostly of glycogen. Kooijman (2010) recalculated the biochemical composition of the reserves in Pacific oyster, referred to as $\boldsymbol{w}_{\boldsymbol{C} \boldsymbol{L} \boldsymbol{P}}$, based on starvation experiments by Whyte et al. (1990). It is therefore possible to obtain another value of $\mu_{E}$, based on these experiments, with a detailed protein, lipid and carbohydrate composition for reserves. We took the following parameters from Kooijman (2010): $\boldsymbol{\mu}_{\boldsymbol{C L P}}$, the conversion factor for the energy content of a mole of carbohydrate, lipid or protein; $\boldsymbol{M}_{\boldsymbol{C H O N}}$, the molar mass for carbon, hydrogen, oxygen and nitrogen and $\boldsymbol{n}_{\boldsymbol{C L P}}$, the CHON composition of a general compound of carbohydrate, lipid or protein (Kooijman, 2010, p. 146 and 150). We thus obtained:

$$
\begin{aligned}
& \mu_{E}=\frac{\boldsymbol{\mu}_{\boldsymbol{C L P}} \boldsymbol{w}_{\boldsymbol{C L P}}}{\boldsymbol{M}_{\boldsymbol{C H O N}} \boldsymbol{n}_{\boldsymbol{C L P}} \boldsymbol{w}_{\boldsymbol{C L P}}} \\
& \text { with } \boldsymbol{\mu}_{\boldsymbol{C L P}}=\left(\begin{array}{lll}
516 & 616401
\end{array}\right), \boldsymbol{w}_{\boldsymbol{C L P}}=\left(\begin{array}{l}
0.341 \\
0.159 \\
0.500
\end{array}\right), \boldsymbol{n}_{\boldsymbol{C L P}}=\left(\begin{array}{ccc}
1 & 1 & 1 \\
2 & 1.92 & 1.61 \\
1 & 0.12 & 0.33 \\
0 & 0 & 0.28
\end{array}\right) \text { and } \boldsymbol{M}_{\boldsymbol{C H O N}}=\left(\begin{array}{llll}
12 & 1 & 16 & 14
\end{array}\right)
\end{aligned}
$$

This calculation gives a value of $\mu_{E}$ equal to $19600 \mathrm{J.g}^{-1}$, which should be compared with the $17500 \mathrm{~J}^{-g^{-1}}$ used in the original model. Calculation of the chemical potential of reserves, $\mu_{E}$, in 
this way seems to be a more accurate approach, because it integrates lipids, carbohydrates and proteins into the description of reserve composition.

The mass ratio of the structure, $d_{V}$, is the ratio between the dry flesh mass and the wet flesh mass of the structure. It corresponds to the mass ratio of oysters without reserves or gonad. Oysters can be found in this condition in the field in winter or after long starvation experiments. Deslous-Paoli and Héral (1988) monitored oyster moisture content in the field over a period of three years. The maximum moisture content of the flesh was $d_{V}=0.15$ in the winter. This value is consistent with the findings of Whyte et al. (1990), who showed that the moisture content of oysters in a starvation experiment stabilised at about 0.86 .

To evaluate the cost of construction, $\left[E_{G}\right]$, we linked it to the chemical potential of structure, $\mu_{V}$, according to the condition $\left[E_{G}\right]>d_{V} \mu_{V}$. $\left[E_{G}\right]$ is an intensive parameter that should therefore not vary between related species. We were therefore able to combine different seasonal studies of variations in the energy content of dry flesh mass to obtain an approximation for $\mu_{V}$ (Tab. 3). With this approach, we obtained a mean value of $15600 \mathrm{~J} . g D F M^{-1}$. Two different techniques were used in these studies to obtain the energy content of the dry flesh mass: an indirect evaluation of protein, lipid and carbohydrate contents or a direct estimation through bomb calorimetry. For estimation of the chemical potential of structure alone, we chose a date on which the condition index or dry flesh mass was minimal, generally at the end of the winter, and calculated the energetic value of the flesh at this time, based on the energy conversions described above. The evaluation of chemical potential based on PLC (proteins, lipids and carbohydrates) generally results in an underestimation of the chemical potential of the flesh, due to the presence of a refractory fraction in the extraction process (Beukema, 1997), whereas bomb calorimetry generally overestimates the chemical potential of the flesh, due to the complete degradation of organic compounds.

We calculated $\left[E_{G}\right]$, by assuming that $60 \%$ of the energy invested in structure building process (van der Veer et al., 2006) and we noted it $\kappa_{G}$. Based on this assumption, $\left[E_{G}\right]=\frac{d_{V} \mu_{V}}{\kappa_{G}}=$ $3900 \mathrm{~J} . \mathrm{cm}^{-3}$ with $\mu_{V}=15600 \mathrm{~J} . \mathrm{g}^{-1}, d_{V}=0.15$ and $\kappa_{G}=0.6$.

The value of $\left\{\dot{p}_{X m}\right\}$ was evaluated from four experiments, see table 4 . In each experiment, the number of cells ingested by oysters, $\dot{J}_{X}$, was calculated from the difference in cell concentration between a tank containing oysters and a similar (control) tank without oysters. Ingestion results for oysters reared in the presence of different phytoplankton concentrations were compiled to obtain a complete description of the functional response. $\dot{J}_{X}$ values were converted into energy, using available data for the biochemical composition of algal species. A logistic functional response describing the variation of ingestion as a function of food concentration $\dot{p}_{X}=\frac{\left\{\dot{p}_{X m}\right\} X}{X+X_{k}}$ was then adjusted to the data, for the determination of $X_{k}$ and $\left\{\dot{p}_{X m}\right\}$. In these four experiments, the mean value of $\left\{\dot{p}_{X m}\right\}$ was $1025 \mathrm{~J} . \mathrm{cm}^{-2} \cdot \mathrm{d}^{-1}$, giving a maximum specific assimilation rate $\left\{\dot{p}_{A m}\right\}$ of $770 \mathrm{~J} . \mathrm{cm}^{-2} \cdot \mathrm{d}^{-1}$, assuming a food assimilation efficiency, $\kappa_{X}$, of 0.75 (van der Veer et al., 2006).

Taking into account the final length, fixed at $45 \mathrm{~cm}$, as in van der Veer et al. (2006), the value of $\left[\dot{p}_{M}\right]$ can be deduced from the relationship $L_{\mathrm{inf}}=\frac{\kappa\left\{\dot{p}_{A m}\right\}}{\delta_{M}\left[\dot{p}_{M}\right]}$. The new value of $\left\{\dot{p}_{A m}\right\}$ thus gives $\left[\dot{p}_{M}\right]=44 \mathrm{~J} \cdot \mathrm{d}^{-1} \cdot \mathrm{cm}^{-3}$. The value of $\left[E_{m}\right]$ was also changed to $4200 \mathrm{~J} . \mathrm{cm}^{-3}$, to ensure that energy conductivity remained similar (van der Veer et al., 2006). These changes improved the simulation of reproductive effort, but the gonado-somatic index triggering spawning in the previous model, $G I$, appeared to be unsuitable for triggering spawning with this new set of parameters. The value of GI triggering spawning at the time of observation is now $46 \%$, based on observed spawning in the current dataset. 


\begin{tabular}{|c|c|c|c|c|}
\hline Species & Date chosen & $\mu_{V}$ in ${\mathrm{J} . \mathrm{gDFM}^{-1}}^{-1}$ & Source & Method \\
\hline \multirow[t]{2}{*}{ Ruditapes decussatus } & Jan. 1980 & 13061 & $\begin{array}{l}\text { Beninger and Lucas } \\
1984 \text {, tab. } 1 \text { and } 2\end{array}$ & PLC \\
\hline & 07/12/1999 & 16071 & $\begin{array}{l}\text { Ojea et al. 2004, tab. } 1 \\
\text { and } 3\end{array}$ & PLC \\
\hline R. philippinarum & Jan. 1980 & 14598 & $\begin{array}{l}\text { Beninger and Lucas } \\
1984 \text {, tab. } 1 \text { and } 2\end{array}$ & PLC \\
\hline Cerastoderma edule & end of Dec. & 11589 & $\begin{array}{l}\text { Navarro et al. 1989, fig. } \\
2\end{array}$ & PLC \\
\hline \multirow[t]{3}{*}{ Mytilus edulis } & 24/02/1977 & 13730 & $\begin{array}{l}\text { Zandee et al. 1980, tab. } \\
1 \text { and } 3\end{array}$ & PLC \\
\hline & Apr. 1992 & 16201 & $\begin{array}{l}\text { Okumus and Stirling } \\
\text { 1998, fig. } 3 \text { and tab. } 2\end{array}$ & PLC \\
\hline & 24/04/1973 & 19267 & $\begin{array}{l}\text { Dare and Edwards } \\
1975 \text {, tab. } 1\end{array}$ & PLC \\
\hline \multirow{6}{*}{ Macoma balthica } & $19 / 02 / 1980$ & 17483 & $\begin{array}{l}\text { Héral and Deslous- } \\
\text { Paoli 1983, tab. } 2\end{array}$ & Calo. \\
\hline & $19 / 02 / 1980$ & 17665 & $\begin{array}{l}\text { Héral and Deslous- } \\
\text { Paoli 1983, tab. } 2\end{array}$ & Calo. \\
\hline & $147^{\text {th }}$ day & 13889 & $\begin{array}{l}\text { Whyte et al. 1990, tab. } \\
1 \text { and } 2 \text { and fig. } 4\end{array}$ & PLC \\
\hline & 19/02/1980 & 10578 & $\begin{array}{l}\text { Deslous-Paoli and } \\
\text { Héral 1988, fig. } 3 \text { and } \\
6\end{array}$ & PLC \\
\hline & Sep. 1996 & 14149 & Kang et al. 2000, fig. 6 & PLC \\
\hline & Mar. 1989 & 18396 & Ruiz et al. 1992, tab. 2 & PLC \\
\hline \multirow[t]{2}{*}{ Macoma balthica } & early Apr. & 15056 & $\begin{array}{l}\text { Beukema and Bruin } \\
1977 \text {, fig. } 1,2 \text { and } 4\end{array}$ & PLC \\
\hline & early Apr. & 22175 & $\begin{array}{l}\text { Beukema and Bruin } \\
1979 \text {, fig. } 3 \text { and tab. } 2\end{array}$ & Calo. \\
\hline
\end{tabular}

\section{Mean}

15600

Table 3: Approximations of the chemical potential of structure for various bivalve species. The date, reference and method of estimation are indicated. Calo: calorimetry studies, PLC: biochemical studies.

\begin{tabular}{rrrr} 
Experiment & Species & $\dot{p}_{X m}$ in ${\mathrm{J} . \mathrm{cm}^{-2} . \mathrm{d}^{-1}} X_{k}$ in $10^{6}$ cells. $^{-1}$ \\
\hline Exp. 1 & Iso. + Chaeto. + Skeleto. & 763 & 48.7 \\
Exp. 2 & Iso. & 1064 & 11.6 \\
Exp. 3 & Rhodo. & 1516 & 9.1 \\
Exp. 4 & Iso. & 758 & 21.1 \\
\hline Mean & & $\mathbf{1 0 2 5}$ & $\mathbf{2 3}$
\end{tabular}

Table 4: Values of $\left\{\dot{p}_{X m}\right\}$ and $X_{k}$ obtained in ingestion experiments with various algae. Iso. = Isochrysis aff. Galbana (T.iso), Chaeto. = Chaetoceros calcitrans, Skeleto. = Skeletonema costatum and Rhodo. = Rhodomonas salina . Data from Y. Bourles (pers. com. 2010). 


\subsection{Values of gonad parameters}

We evaluated the new parameters, to ensure consistency with published data on energy and dry flesh mass in $C$. gigas and related species. In the standard DEB model for $C$. gigas, only the ratio between dry mass and wet mass for structure was used to calculate total dry flesh mass. As shown by Deslous-Paoli and Héral (1988), the whole mass ratio of the oyster changes greatly with reserve content and gametogenesis stage: from 0.15 in winter to 0.27 in summer. This suggests that the mass ratio must be different for reserves, gonad and structure. This result led us to combine together the mass ratio for the various compartments, to obtain a mass ratio for the whole body.

The mass ratio of the gonad, $d_{G o}$, is the ratio of dry flesh mass to wet flesh mass for the gonad. If we assume a constant ratio for each compartment, the mass ratio for the gonad can be quantified by determining the difference between the mass ratios observed before and after spawning. It can thus be calculated as $\left(M R_{b s}-\frac{D F M_{a s}}{D F M_{b s}} M R_{a s}\right)\left(\frac{D F M_{b s}}{D F M_{b s}-D F M_{a s}}\right)$, where $b s$ is the measured ratio "before spawning" and $a s$ is that "after spawning". Assuming $D F M_{b s}=1.88 \mathrm{~g}$, $D F M_{a s}=1.07 \mathrm{~g}, M R_{b s}=0.243$ and $M R_{a s}=0.196$ from Deslous-Paoli and Héral (1988), gives an estimate of $d_{G o}=0.31$.

The energy allocated to gonad construction, $E_{G o}$, is transformed into gonad mass with the same equation used for structure: $D F M_{G o}=E_{G o} d_{G o} /\left[E_{G o}\right]$ where $d_{G o}$ is the ratio between dry flesh mass and wet flesh mass for the gonad and $\left[E_{G o}\right]$ is the specific cost of gonad construction. The value of $\left[E_{G o}\right]$ is evaluated as described for $\left[E_{G}\right]$, see section 2.3. A compilation of studies on energetic values for the gonad in C. gigas and related species resulted in an estimate of 21630 $\mathrm{J.gDFM}^{-1}$ for the chemical potential of gonad, see table 5. If we assume that $90 \%$ of the energy invested in the gonads is used for construction, $\kappa_{G o}=0.9$, we obtain a value of $\left[E_{G o}\right]=$ $7500 \mathrm{~J} . \mathrm{cm}^{-3}$.

\begin{tabular}{rrrr} 
Species & $\mu_{G O}$ in J.gDFM & Method & Source \\
\hline C. gigas & 25660 & unknown & Hyun et al. (2001, tab. 1) \\
C. gigas & 18605 & PLC & Deslous-Paoli and Héral (1988, tab. 1) \\
C. gigas & 17050 & PLC & Ren et al. (2003, fig. 7) \\
C. gigas & 21525 & PLC & Berthelin et al. (2000, fig. 2) \\
C. gigas & 27762 & Calorimetry & Héral and Deslous-Paoli (1983, tab. 2) \\
C. plicatula & 19448 & PLC & Li et al. (2006, tab. 1) \\
Ostrea edulis & 19061 & Calorimetry & Rodhouse (1978, in text) \\
Patella vulgata & 23950 & Calorimetry & Workman (1983, tab. 2) \\
Chlamys varia & 22157 & Calorimetry & Shafee and Lucas (1980, in text) \\
\hline Mean & $\mathbf{2 1 6 3 0}$ & &
\end{tabular}

Table 5: Approximations of the chemical potential of the gonad, $\mu_{G O}$, for various species.

The addition of a new state variable improved description of the experiment of Li et al. (2009). In this experiment, a single population of oysters was divided into two subpopulations: one in which spawning was induced before the experiment and one without spawning induction. These two subpopulations were then starved. The main result of this experiment was a difference in the rate of weight loss between the two subpopulations (Fig. 2). The form of this difference could not be correctly represented by the DEB model of Bourlès et al. (2009), but can now be described with the specific assumption added for the description of the gonad and its resorption in 
cases of extreme starvation. The calibration of the model with these data gave a gonad resorption yield, $Y_{G o}$, of 0.25 .

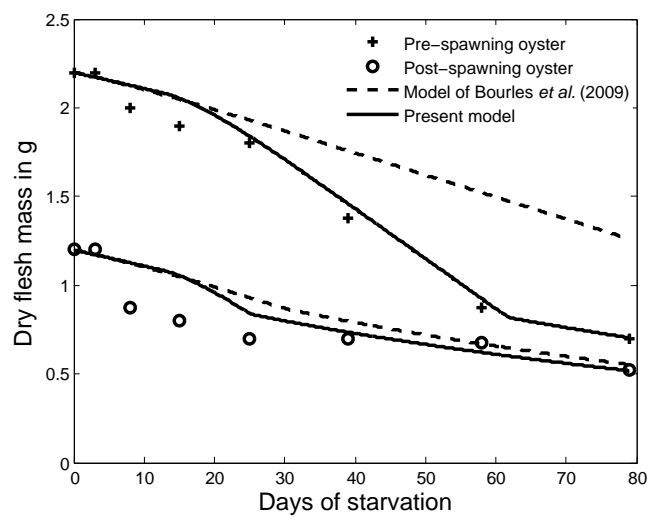

Figure 2: Simulation of the starvation experiment of Li et al. (2009) by the model of Bourlès et al. (2009) and the extended model for gonad presented here.

\subsection{Datasets and forcing variables}

For the purposes of this study, a one-year-old oyster population was transplanted to four sites along the French coast in 2008 and 2009. These sites were chosen because they were either traditional spat-collecting areas, such as the bay of Arcachon and the bay of Marennes-Oléron, or new areas of natural reproduction in which $C$. gigas is invasive, such as the bay of Bourgneuf or the bay of Brest (Fig. 3). Oysters were transplanted each year, at the beginning of March, i.e. before the start of gametogenesis. A sample of 30 individuals was collected from each site once every fortnight. The flesh of each oyster was drained until all free water had been released and was then weighed to obtain wet flesh mass (WFM). The flesh was then freeze-dried to remove all the remaining water, to obtain the dry flesh mass (DFM).

At each site, water temperature was measured with a high-frequency probe that took one measurement every 30 minutes. Daily mean temperature was then calculated for use as a forcing variable. For Arrhenius correction of the rates in both models, daily mean temperature was smoothed, through the use of a moving average with a five-day span. Arrhenius correction of rates was then applied for both assimilation and maintenance rates, as described by Bourlès et al. (2009), using the parameters described in table 2.

As in the study by Bourlès et al. (2009), food was also quantified at each site. Data were obtained from the IFREMER REPHY network, which identifies and counts phytoplankton species. The following method was used: duplicate samples of 1 litre of water each were sampled at a depth of 1 metre below the surface. These samples were immediately fixed with lugol solution $(1 \mathrm{~mL}$ per litre of sea water). Phytoplankton species were then identified and counted under a light microscope, by an experienced technician, at the laboratory. These data were interpolated daily, by piecewise cubic Hermitian interpolation (pchip) in Matlab R14 (The MathWorks Inc.).

\subsection{Field and theoretical simulations}

Simulations were made in both Matlab R14 (The MathWorks Inc.) and STELLA 8.1 (High Performance Systems Inc.) software, with both programs giving similar results, with only slight 


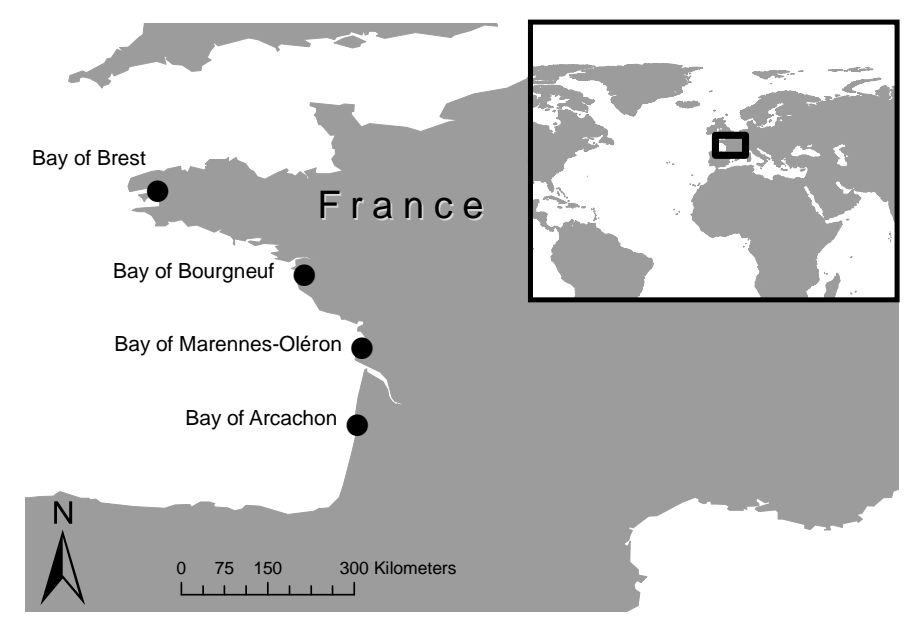

Figure 3: Location of the four study sites along the Atlantic coast of France

differences due to differences in the integration procedures used.

For field simulations, the state variables of the model were initialised by making assumptions about the energy distribution of the oyster at the start of the experiments. The gonad compartment was considered empty and the proportion of energy in each compartment were selected so as to reproduce both the dry flesh mass and the mass ratio observed at the beginning of the experiment. Dry flesh mass was obtained from the four state variables, with the following equation (Eq. 2):

$$
D F M=\frac{E+E_{R}}{\mu_{E}}+\frac{E_{V} d_{V}}{\left[E_{G}\right]}+\frac{E_{G o} d_{G o}}{\left[E_{G o}\right]}
$$

We calibrated $X_{k}$ manually to obtain the observed dry flesh mass before spawning. The goodness of fit of the simulation was evaluated by calculating the coefficient of determination, $R^{2}$, between observed and simulated values, and $a$, the slope of the regression $\widehat{X}=a X$, where $\widehat{X}$ are simulated values and $X$ observed values. We evaluated the goodness of fit of the reproductive effort, $R E$, of the model, by calculating the proportion of error with respect to the observed reproductive effort as: $S=\frac{\left|R E_{o b s}-R E_{s i m}\right|}{R E_{o b s}} . R E_{o b s}$ and $R E_{\text {sim }}$ were estimated by calculating the difference in dry flesh mass before and after spawning, on the sampling dates.

For theoretical simulations, the spring bloom was modelled with the Gaussian equation: $X=a_{X} \exp \left(-\frac{\left(t-b_{X}\right)^{2}}{2 c_{X}}\right)+d_{X}$, where $a_{X}$ is the concentration at the peak of the bloom, $b_{X}$ is the Julian day on which the bloom occurred, $c_{X}$ is the duration of the bloom and $d_{X}$ is the concentration of phytoplankton outside the bloom period. Only the parameters $b_{X}$ and $c_{X}$ vary in theoretical simulations, because $a_{X}$ and $d_{X}$ values are fixed at commonly observed values, $1.810^{6}$ cells. $\mathrm{L}^{-1}$ and $210^{5}$ cells. $\mathrm{L}^{-1}$, respectively. The temperature is described by the sinusoidal function used for the beginning and ending of gonad construction, with variation of the parameters $a_{T}$ and $b_{T}$, whereas $c_{T}$ and $b_{T}$ are fixed at the commonly observed values $2 \pi / 365$ and -2.07 , respectively. For each of the four parameters varying in theoretical simulations, we chose to study 11 values from the range of variation observed in the dataset for each parameter. To improve the representation, in simulations for which spawning triggers were never fulfilled, results were replaced by a very late spawning date and by the overall mean for the number of oocytes produced. 


\section{Results}

\subsection{Field simulations with the two versions of the model}

The simulations obtained with the model of Bourlès et al. (2009) is consistent with observations for both the spring and summer periods, but show a low fit for the autumn period (Fig. 4). In spring, an exception was identified for the bay of Brest in 2009, for which the growth observed in April and May is not reproduced by the model, whatever the $X_{k}$ parameter chosen. However, despite these reasonably good descriptions of spring growth, simulations with this version of the DEB model do not accurately reflect the magnitude of the reproductive effort in summer. This effort was greatly underestimated in the bay of Marennes-Oléron, in both years (errors of 59 and $38 \%$ for 2008 and 2009, respectively), in the bay of Bourgneuf (errors of 35\% and 29\% for 2008 and 2009, respectively) and in the bay of Arcachon in 2009 (error of 41\%), see table 7. Reproductive effort was simulated satisfactorily in the bay of Arcachon and bay of Brest in 2008. In autumn, oyster dry flesh mass was greatly overestimated for Arcachon in 2009 and for the bay of Bourgneuf in both years. The other simulations, for the bays of Arcachon, Marennes-Oléron and Brest in 2008, are more satisfactory, although some small discrepancies are observed, e.g. for Marennes-Oléron in 2008, for which the simulated autumnal growth is more pronounced than the observed growth.

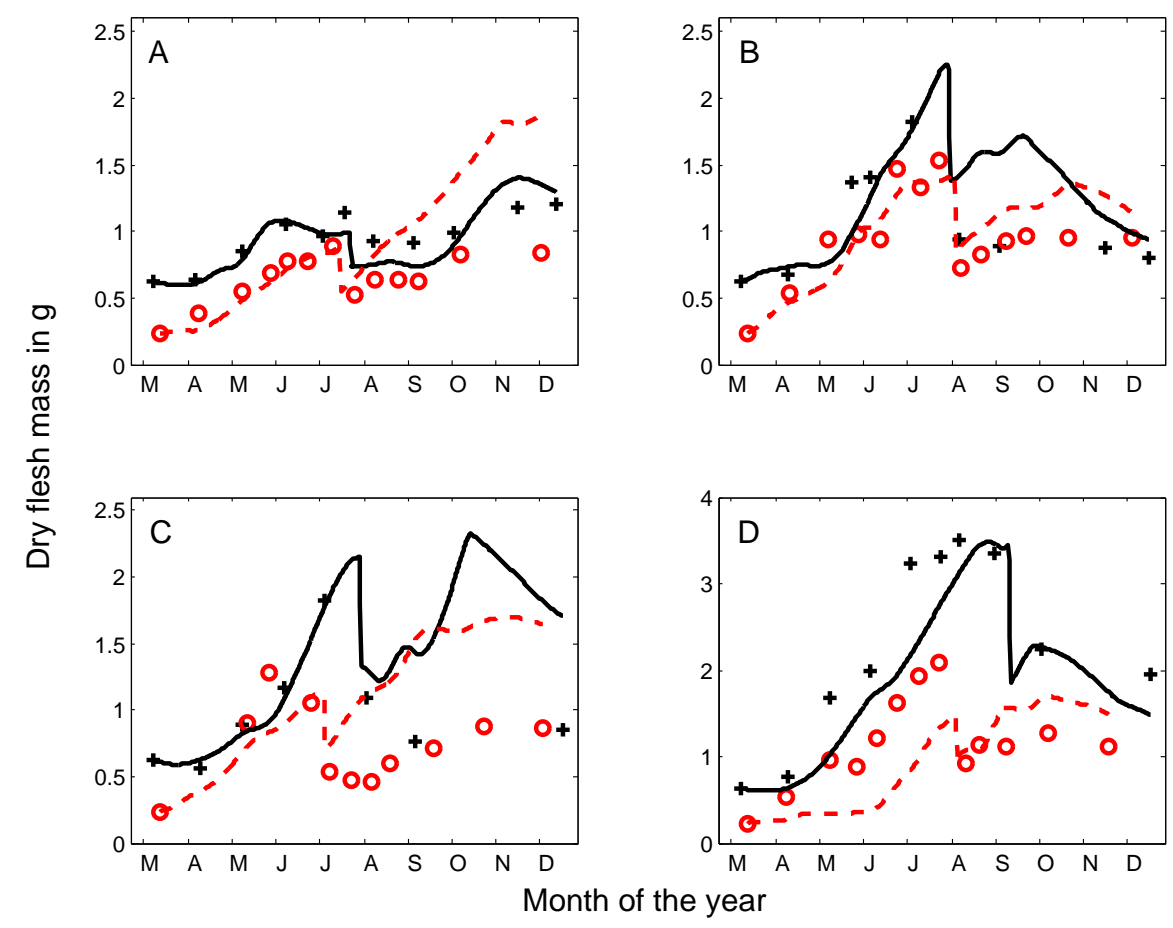

Figure 4: Simulations (continuous line for 2008 and dotted line for 2009) of the observed dry flesh mass (crosses for 2008 and circles for 2009), based on the DEB model of Bourlès et al. (2009) for the Bay of Arcachon (A), the bay of Marennes-Oléron (B), the bay of Bourgneuf (C) and the bay of Brest (D). 
Two sets of data stand out for having very high calibrated values of $X_{k}$ : the bay of Arcachon, in 2008 and the bay of Brest in 2009 (Tab. 6). In the bay of Brest in April and May 2009, some of the phytoplankton samples were lost. $X_{k}$ is thus underestimated in this simulation, due to an underestimation of the forcing variable. This also explains the poor description of spring growth for these datasets. The highest $X_{k}$ value is that obtained for Arcachon bay in 2008. During this season, no oyster growth was observed in Arcachon despite a high phytoplankton concentration (2008 mean: 390000 cells. $\mathrm{L}^{-1}$ ), resulting in a value of $0.8810^{6}$ cells. $\mathrm{L}^{-1}$ for $X_{k}$. By contrast, relatively low values are used for the bay of Brest in 2008 and the bay of Arcachon in 2009.

Simulations made with the new version of the model differ only slightly from those made with the previous version (Fig. 5). In spring, predicted growth closely matches observations for almost every simulation, but the same exceptions persist for the simulation of the year 2009 in the bay of Brest. In summer, reproductive effort is better reproduced by the new version of the model at almost all sites; the error on spawning is less than $20 \%$ for four simulations, see table 7. Three simulations of spawning show no improvement with the new model: the bay of Brest in 2008 and 2009, where no difference is observed, and the bay of Arcachon in 2008, where the new model estimates spawning effort at twice the observed value. In autumn, no improvement is shown in this version compared with the previous one and the same discrepancies occur at the same sites and in the same years. The values of $X_{k}$ used in the revised model are systematically higher than those for the previous model, but yield the same variations between sites and years.

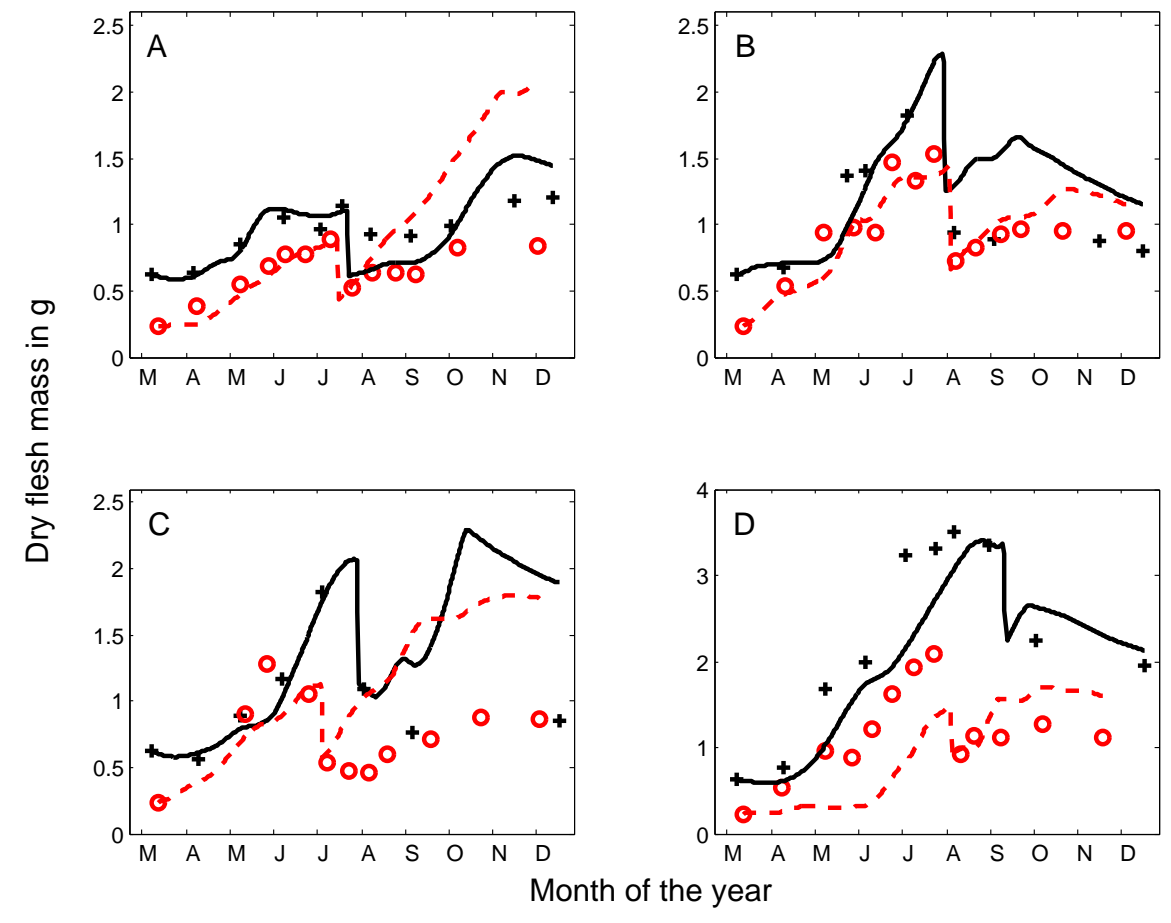

Figure 5: Simulations (continuous line for 2008 and dotted line for 2009) of observed dry flesh mass (crosses for 2008 and circles for 2009) with the extended DEB model for the bay of Arcachon (A), the bay of Marennes-Oléron (B), the bay of Bourgneuf (C) and the bay of Brest (D). 


\begin{tabular}{c|rr|rr|rr|rr} 
& \multicolumn{2}{|c|}{ Arcachon } & \multicolumn{2}{|c|}{ Marennes-Oléron } & \multicolumn{2}{c}{ Bourgneuf } & \multicolumn{2}{c}{ Brest } \\
& 2008 & 2009 & 2008 & 2009 & 2008 & 2009 & 2008 & 2009 \\
\hline Bourles & 0.88 & 0.36 & 0.57 & 0.45 & 0.45 & 0.55 & 0.27 & 0.18 \\
Present & 1.2 & 0.45 & 0.85 & 0.63 & 0.73 & 0.72 & 0.48 & 0.27 \\
\hline
\end{tabular}

Table 6: Values of $X_{k}$ used in simulations, in $10^{6}$ cells. $\mathrm{L}^{-1}$.

If we compare the two versions of the DEB model on the basis of the spawning indicator $S$ (Tab. 7), a large improvement can be seen with the new version of the model, which fails to reproduce the reproductive effort only for certain sites and some years. However, on the basis of global indicators, such as $R^{2}$ or the slope of the regression $a$ (Tab. 7), no clear evidence of improvement emerges, with $R^{2}$ and slopes fairly similar for all simulations. Neither model correctly reproduced growth variation in the bay of Bourgneuf: $R^{2}$ are low for 2008 and 0 for 2009 , while the slope shows a clear overestimation of the recorded data by the models. This poor fit may be accounted for by the sampling of the phytoplankton at this site at some distance from the study site housing the oysters.

\begin{tabular}{cc|cc|cc|cc|cc}
\multicolumn{2}{c|}{} & & \multicolumn{2}{|c|}{ Arcachon } & \multicolumn{2}{c|}{ Marennes-Oléron } & \multicolumn{2}{c|}{ Bourgneuf } & \multicolumn{2}{c}{ Brest } \\
\hline$R^{2}$ & Model & 2008 & 2009 & 2008 & 2009 & 2008 & 2009 & 2008 & 2009 \\
\hline & Bourles & 0.78 & 0.44 & 0.33 & 0.54 & 0.35 & 0.00 & 0.86 & 0.13 \\
$a$ & Present & 0.76 & 0.44 & 0.33 & 0.66 & 0.27 & 0.01 & 0.77 & 0.14 \\
& Bourles & 0.97 & 1.32 & 1.05 & 1.04 & 1.15 & 1.35 & 0.86 & 0.72 \\
& Present & 1.02 & 1.34 & 1.07 & 1.00 & 1.11 & 1.36 & 0.88 & 0.71 \\
& Bourles & 0.08 & 0.41 & 0.59 & 0.38 & 0.35 & 0.29 & 0.07 & 0.78 \\
& Present & 1.03 & 0.12 & 0.43 & 0.18 & 0.09 & 0.03 & 0.33 & 0.69 \\
\hline
\end{tabular}

Table 7: Comparison of three indicators of the goodness of fit for simulations with the Bourles model and the model presented here. $R^{2}$ is the coefficient of determination, a is the slope of the regression of predicted values against observed values and $S$ is the error made on reproductive effort

\subsection{Theoretical simulations}

We report here our use of the improved version of the model to investigate the combined effect of temperature and phytoplankton on reproductive effort and spawning date. We carried out theoretical simulations with four varying parameters, at low (Fig. 6) and high (Fig. 7) $X_{k}$ values. For each simulation, spawning date and the number of oocytes produced were calculated when spawning triggers were fulfilled. The values obtained for each combination of parameters were projected onto a two-dimensional plane by taking means for the other two dimensions.

At low values of $X_{k}$, indicating high food quality, the main factor influencing spawning date is temperature: yearly mean temperature in particular (Fig. 6). The threshold of $19{ }^{\circ} \mathrm{C}$ is the final trigger condition to be fulfilled in this case. If this temperature threshold is not reached, no spawning occurs - as in the left bottom corner of figure (Fig. 6). The food forcing variable has an effect on spawning date only if the phytoplankton bloom occurs after April, i.e. after the $130^{\text {th }}$ day of the year. As a result, spawning date varied between the end of June (Julian day 175) and mid July (Julian day 195). The number of oocytes produced depends on both temperature and food. For temperature, yearly amplitude is the main factor affecting the number of oocytes produced whereas, for food, the main factor is the duration of the bloom. If the bloom occurs 
late in the season, spawning is delayed, but more oocytes are produced, as gametogenesis occurs over a longer period in warmer waters.
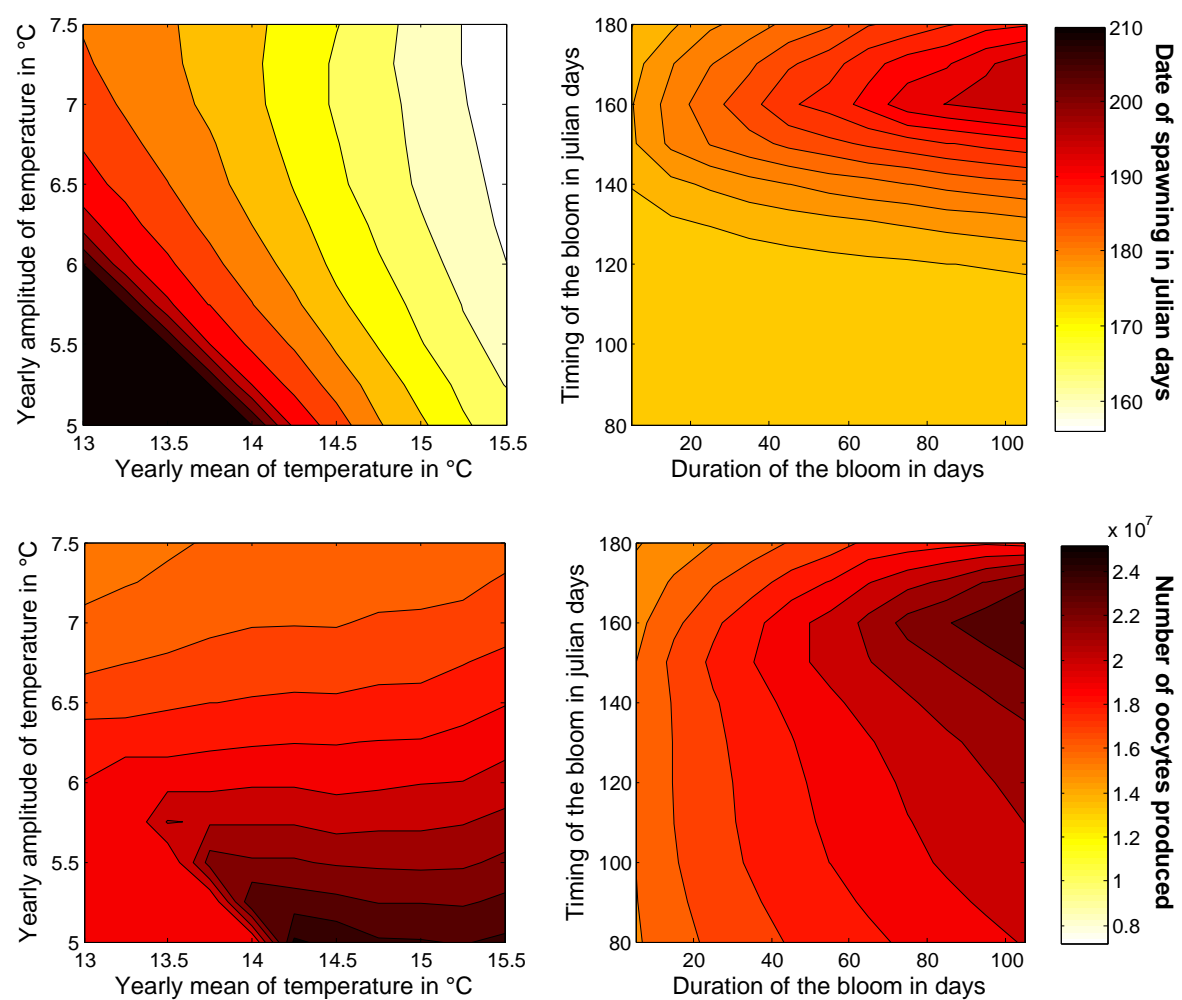

Figure 6: Theoretical simulations of spawning date (top) and the number of oocytes produced (bottom) with a low $X_{k}$ value $\left(X_{k}=0.4510^{6}\right.$ cells. $\left.\mathrm{L}^{-1}\right)$ for four varying parameters: yearly temperature amplitude and yearly mean temperature; timing and duration of spring bloom. The results obtained are projected onto two-dimensional planes for temperature (left) and food parameters (right).

At high values of $X_{k}$, corresponding to low food quality, a similar pattern was observed for spawning date. Yearly mean temperature is again the main factor affecting spawning date (Fig. 7). However, early blooms, i.e. occurring before mid March, cause more delay to spawning date: from the end of June (Julian day 175) to the end of July (Julian day 208). If we compare these results with those presented in the previous figure, we can see that the spawning date is delayed by the same combination of parameters. When $X_{k}$ has a high value, temperature does not influence the number of oocytes produced. Comparison with the previous figure shows that both temperature and bloom effects on the number of oocytes produced are negligible compared with the effect of the $X_{k}$ parameter. 

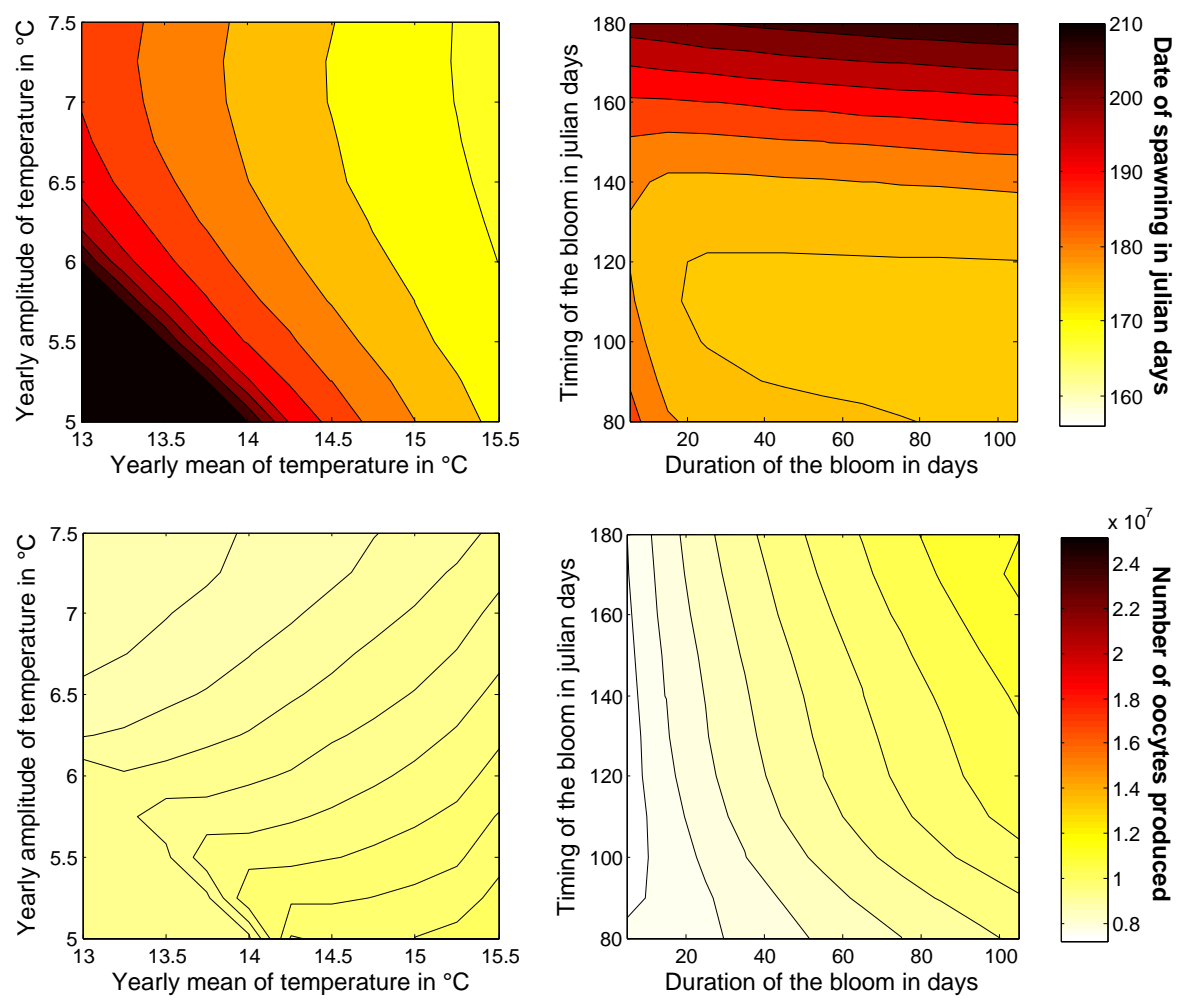

Figure 7: Theoretical simulations of spawning date (top) and the number of oocytes produced (bottom) with a high $X_{k}$ value $\left(X_{k}=1.210^{6}\right.$ cells. $\left.\mathrm{L}^{-1}\right)$ for four varying parameters: yearly temperature amplitude and yearly mean temperature, and timing and duration of the spring bloom. The results obtained are projected onto two-dimensional planes for temperature (left) and food parameters (right). 


\section{Discussion}

\subsection{Improvement of the model}

In this study, we modified the value of five important parameters in the oyster DEB model: $\left\{\dot{p}_{A m}\right\},\left[\dot{p}_{M}\right],\left[E_{G}\right],\left[E_{m}\right]$ and $\mu_{E}$. We also increased the complexity of the description of energy allocation to reproduction by adding one state variable $E_{G o}$ and three related parameters: $d_{G o}$, $\left[E_{G o}\right]$ and $Y_{G o}$. These changes do not fundamentally alter the dynamics of the model, as only slight differences are detected between the two sets of simulations we made, but our modifications improve the estimation of reproductive effort at spawning. These similar dynamics for two different versions of the DEB model indicate that future research must focus more on energy acquisition than on energy use.

Concerning the re-estimation of parameters, higher $\left\{\dot{p}_{A m}\right\}$ values increase the rate of energy intake by oysters, but this additional energy is dissipated by increases in the cost of maintenance $\left[\dot{p}_{M}\right]$ and the cost of construction of structure and gonad, $\left[E_{G}\right]$ and $\left[E_{G o}\right]$. In short, in this model, the oyster is able to obtain more energy from the environment to construct flesh with a higher energy content. By contrast to the previous version described by van der Veer et al. (2006), this new version of the model is consistent with ingestion experiments giving a $\left\{\dot{p}_{A m}\right\}$ value of 770 $\mathrm{J} . \mathrm{cm}^{-2} \cdot \mathrm{d}^{-1}$. This value is close to the value of $670 \mathrm{~J} . \mathrm{cm}^{-2} \cdot \mathrm{d}^{-1}$ reported by Ren and Schiel (2008) at $20^{\circ} \mathrm{C}$. This parameter is one of the most sensitive of the model (Bacher and Gangnery, 2006), but its modification can lead to a similar dynamic if the parameters controlling energy use are also changed. The parameter values used here remain debatable, and their evaluation must be considered a continuing process (for parameters estimation, see Saraiva et al., 2011, this issue). However, based on the results of this work, we suggest that determination of the value of $\left\{\dot{p}_{A m}\right\}$, associated with the energy content of the flesh, should be the first step for parameter evaluation.

It proved difficult to find a simple rule for activation of the flux of gamete mobilization and to develop a suitable formulation for this. Modifications to the standard DEB model of this type have already been proposed by Pecquerie et al. (2009) for anchovy. For the beginning and ending of gametogenesis, the anchovy models initiate the batch preparation of eggs if surface temperature exceeds a particular threshold and the preparation ends when there is no longer enough energy available (Pecquerie et al., 2009). We used a derivative of temperature as the signal for beginning and ending gametogenesis because, for oysters, the threshold seems to be site-specific and thus difficult to fix (Ruiz et al., 1992; Castaños et al., 2009). Pecquerie et al. (2009) proposed a flux based on catabolic flux, which depends on the structural volume, $V$, alone, with no effect of reproductive reserves. We also derived the flux of gamete mobilization from the catabolic flux and obtained a complex energy flux dependent on the reproductive reserves, $E_{R}$. It permits us to obtain a flux that stops if $E_{R}$ is empty. As this flux is also used in winter to meet somatic maintenance costs, theoretical considerations are still required, to find a simpler formulation with an axiomatic approach, compatible with DEB theory.

A key feature of this model that is crucial for energy allocation to reproduction is its flexibility concerning the origin of the energy required to satisfy maintenance costs. Our new version effectively describes an auxiliary mobilisation rate of energy from the buffer allocated to reproduction, and even from an existing gonad. With these changes, the model is close to describing a "supply system" for organisms fixed in place for feeding. The addition of resorption processes to the model, such as the mobilisation of energy from the gonad, increases the ability of the model to simulate the temporal adaptation, by the organism, of the amount of energy it allocates to reproduction: the amount of energy allocated to reproduction is never definitive and the resulting investment in reproduction may therefore be very different from expectations based on " $\kappa$-rules", 
which postulate that a constant fraction of energy is allocated to reproduction. From an evolutionary perspective, this feature may have additional implications, because it strengthens the link between reproductive effort and environmental variability.

\subsection{Insight gained from modelling}

At low $X_{k}$ values (high food quality), spawning date depends principally on temperature, consistent with the day-degree method used in hatcheries to determinate when oysters are ripe (Mann, 1979). However, the application of this method in the field has been shown to be problematic (Steele and Mulcahy, 1999), perhaps because food quantity and quality were not taken into account. This was confirmed by our results, which indicate that the day-degree method would not be able to predict the date of gonad maturity in an environment in which the quantity and quality of food did not remain constant.

In invasive species, temperature is often seen as imposing the northern limit for spawning and, thus, as the factor limiting northward expansion (Diederich et al., 2005; Wrange et al., 2009). Spawning may occur in this context, but resorption occurs in other, cooler, years. We estimate the energy yield of emergency resorption to be $25 \%$ and, if we assume that the yield of resorption is the same in the absence of spawning, this represents the reallocation of a large amount of energy to reproduction in the next year. Such a mechanism has already been proposed to account for the ability of oysters from productive ecosystems to achieve gametogenesis without food (Cannuel and Beninger, 2005). In ecosystems in which spawning does not occur every year, this mechanism may therefore increase the variability of the number of gametes released and facilitate the invasion of northern areas when conditions are favourable.

The most striking difference in growth was observed in 2008, between the bay of Brest and the bay of Arcachon. This difference in growth does not seem to be related to phytoplankton concentration, because bloom sizes are similar at these two sites (data not shown). In our simulations, this difference in growth at the same phytoplankton concentration affected the $X_{k}$ value: $0.4810^{6}$ cells. $\mathrm{L}^{-1}$ for Brest, versus $1.210^{6}$ cells. $\mathrm{L}^{-1}$ for Arcachon. Our theoretical simulations show that this parameter has a profound effect on reproductive effort. Another illustration of the impact of $X_{k}$ value on reproduction is provided by the simulation of the year 2008 for the bay of Arcachon. If we relax the spawning at a fixed date conditions used in the results section and instead make use of environmental triggers, it is possible to obtain a better simulation by slightly increasing $X_{k}$ (Fig. 8). With a higher value for $X_{k}$, spawning no longer occurs, because gonad resorption begins before the gonado-somatic ratio for spawning is reached. This simulation without spawning give results closer to the observed dry flesh mass until autumn and reproduces the slow decrease in dry flesh mass in June, with only a small change in the value of $X_{k}$. Very high values of $X_{k}$ may thus even impede spawning in some cases.

As previously pointed out (S. Pouvreau 2009, personal communication), $X_{k}$ variability between simulations is a black box that still includes a mixture of different effects, such as food quality and the quality of the proxy used as a forcing variable (e.g. simulation of the bay of Brest in 2009), phenotypic variability, zootechnical conditions or pollution effects. The variability of $X_{k}$ poses a problem in the DEB models for almost all shellfish species (Pouvreau et al., 2006; Ren and Schiel, 2008; Rosland et al., 2009; Troost et al., 2010).

One way of improving the food proxy used in DEB models is to add other trophic resources. Isotopic studies have revealed that oysters have other complementary sources of food (e.g. Lefebvre et al., 2009). The further development of the oyster DEB model with isotope dynamics may provide additional information about the importance of complementary food sources (see Emmery et al., 2011, this issue). 


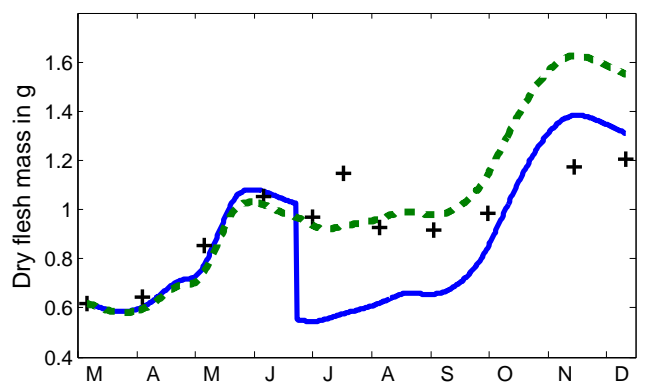

Figure 8: Simulations in Arcachon Bay in 2008, using spawning triggers, with $X_{k}=1.210^{6}$ cells.L $\mathrm{L}^{-1}$ (continuous line) and $X_{k}=1.410^{6}$ cells. $L^{-1}$ (dotted line).

Another approach would involve focusing on improving the available food proxy chosen (Bourlès et al., 2009). The use of phytoplankton cell counts has raised questions about the quality of some phytoplankton species, such as Leptocylindrus minimus (S. Pouvreau 2009, personal communication) or Tetraselmis suecica (Bourlès et al., 2009). An important assumption concealed behind the functional response of the DEB model is that $C$. gigas displays the same behaviour with all species of phytoplankton, although a valvometry study by Tran et al. (2010) showed that this is not the case when comparing a non-toxic alga, Isochrysis galbana, with a toxic species, Alexandrium minutum. Moreover, Comeau et al. (2010) showed, by studying chlorophyll uptake, that oysters may not feed on some autumn blooms.

On a more fundamental level, even the choice of the equation for the functional response has an impact on model dynamics (Fussmann and Blasius, 2005). Poggiale et al. (2010) showed that this effect also occurs with more complex models, such as the DEB model of nutrientphytoplankton-zooplankton food chains. They reached the same conclusion as Gentleman and Neuheimer (2008): details of physiological uptake are of primordial importance for the dynamics of the model.

Finally, both experimental and fundamental analyses have highlighted the need for more detailed field studies on the phytoplankton diet of oysters. We suggest that further progress in studies of oyster phytoplankton preferences could be made in the field, through the use of experimental designs such as that involving the apparatus described by Comeau et al. (2010). We see little point in further increasing the complexity of this DEB model until the issue of phytoplankton quality is better understood.

\section{Conclusion}

In conclusion, our results highlight the sensitivity of this DEB model to the parameters of the functional response. We show here that a change in the value of the maximum assimilation rate, $\left\{\dot{p}_{A m}\right\}$, allowed a better respect of experimental information concerning the energy content of the flesh, without changing the overall dynamics, if we also simultaneously change three fundamental parameters: $\left[\dot{p}_{M}\right],\left[E_{G}\right]$ and $\left[E_{m}\right]$. In theoretical simulations, it appears that spawning date is driven by mean annual temperature and is disconnected from food abundance, with only a slight effect of the value of the half-saturation coefficient, $X_{k}$. However, reproductive effort depends strongly on the value of $X_{k}$. As the variations of this parameter in the field remain poorly 
understood, we urge that new field studies be made on phytoplankton preferences of oysters to pursue our comprehension of the reproductive effort.

\section{Acknowledgements}

This research was part of the VeLyGer project supported by the French Ministry of Agriculture (DPMA), the European Community (FEP) and IFREMER (conv. n³0 114-2008). This study benefited from intensive discussions with D. Maurer, I. Auby and members of the AquaDEB group led by M. Alunno-Bruscia. It was made possible by the assistance of the personnel from IFREMER LER, who carried out biometric measurements of oysters in the field: F. d'Amico for the bay of Arcachon, S. Robert, P. Guilpain, and J.-L. Seugnet for the bay of MarennesOléron, S. Breerette and B. Hitier for the bay of Bourgneuf and P. Le Souchu for the bay of Brest. This work also made intensive use of the abundances of phytoplankton species measured by the REPHY network, led by C. Belin. Finally, I. Bernard would like to thank IFREMER and the Conseil Regional de Poitou-Charentes (France) for providing support for this study in the form of a scholarship. Finally, we would like to thank H. McCombie and Julie for the English correction of this manuscript.

\section{AppendixA. Derivation of gamete mobilization from the reproductive reserve}

The dynamics of $E_{R}$ was derived in the same way as the dynamics of $E$ in Kooijman (2010, p. 37-41). If, for the sake of simplicity, we ignore $\dot{p}_{J}$, then we can write:

$$
\frac{d E_{R}}{d t}=(1-\kappa) \dot{p}_{C 1}-\dot{p}_{C 2}
$$

Assuming that $\left[E_{R}\right]=E_{R} / V$, the equation A.1 becomes:

$$
\frac{d\left[E_{R}\right]}{d t}=(1-\kappa)\left[\dot{p}_{C 1}\right]-\left[\dot{p}_{C 2}\right]-\frac{\left[E_{R}\right]}{V} \frac{d V}{d t}
$$

where $\left[\dot{p}_{C *}\right]$ is $\dot{p}_{C *} / V$, with * equal to 1 or 2 . obtain:

Furthermore, as we also know that $\frac{d V}{d t}=\frac{\kappa \dot{p}_{C 1}-\dot{p}_{M 1}}{\left[E_{G}\right]}$, from the previous equation (Eq. A.2) we

$$
\frac{d\left[E_{R}\right]}{d t}=(1-\kappa)\left[\dot{p}_{C 1}\right]-\left[\dot{p}_{C 2}\right]-\left[E_{R}\right] \frac{\kappa\left[\dot{p}_{C 1}\right]-\left[\dot{p}_{M 1}\right]}{\left[E_{G}\right]}
$$

Moreover, as for the dynamics of reserves (page 37), the general form of the dynamics of $\left[E_{R}\right]$ can be written as:

$$
\frac{d\left[E_{R}\right]}{d t}=(1-\kappa)\left[\dot{p}_{C 1}\right]-H\left(\left[E_{R}\right] \mid V\right)+\left(\left[E_{R}^{*}\right]-\left[E_{R}\right]\right) G\left(\left[E_{R}\right] \mid V\right)
$$

where $H$ and $G$ are functions of $\left[E_{R}\right]$ and $V$, and $G$ is a function that is null at steady state. Due to the seasonal dynamics of $\left[E_{R}\right]$, the concept of equilibrium is meaningless here and $G$ is thus assumed to be null. As $E$ and $E_{R}$ are of the same nature, the same $F$ function used in the development of $E$ dynamics (page 39) can also be used here: $F=\left\{\dot{p}_{A m}\right\} /\left[E_{m}\right] V^{-1 / 3}\left[E_{R}\right]$. We thus obtain the following formula:

$$
\frac{d\left[E_{R}\right]}{d t}=\underset{20}{(1-\kappa)\left[\dot{p}_{C 1}\right]}-\frac{\left\{\dot{p}_{A m}\right\}\left[E_{R}\right]}{\left[E_{m}\right] V^{1 / 3}}
$$


From equation A.5 and A.3, we now obtain the formula for $\left[\dot{p}_{C 2}\right]$ :

$$
\begin{aligned}
{\left[\dot{p}_{C 2}\right] } & =(1-\kappa)\left[\dot{p}_{C 1}\right]-\frac{d\left[E_{R}\right]}{d t}-\left[E_{R}\right] \frac{\kappa\left[\dot{p}_{C 1}\right]-\left[\dot{p}_{M 1}\right]}{\left[E_{G}\right]} \\
& =\frac{\left\{\dot{p}_{A m}\right\}}{\left[E_{m}\right] V^{1 / 3}}\left[E_{R}\right]-\left[E_{R}\right] \frac{\kappa\left[\dot{p}_{C 1}\right]-\left[\dot{p}_{M 1}\right]}{\left[E_{G}\right]} \\
& =\left[E_{R}\right]\left(\frac{\left\{\dot{p}_{A m}\right\}}{\left[E_{m}\right] V^{1 / 3}}+\frac{\left[\dot{p}_{M 1}\right]}{\left[E_{G}\right]}-\frac{\kappa\left[\dot{p}_{C 1}\right]}{\left[E_{G}\right]}\right) \\
& =\left[E_{R}\right]\left(\frac{\left\{\dot{p}_{A m}\right\}}{\left[E_{m}\right] V^{1 / 3}}+\frac{\left[\dot{p}_{M 1}\right]}{\left[E_{G}\right]}-\frac{\kappa[E]\left\{\dot{p}_{A m}\right\}}{\left[E_{m}\right] V^{1 / 3}\left(\left[E_{G}\right]+\kappa[E]\right)}-\frac{\left[\dot{p}_{M 1}\right] \kappa[E]}{\left[E_{G}\right]\left(\left[E_{G}\right]+\kappa[E]\right)}\right) \\
& =\left[E_{R}\right]\left(\frac{\left\{\dot{p}_{A m}\right\}}{\left[E_{m}\right] V^{1 / 3}}+\frac{\left[\dot{p}_{M 1}\right]}{\left[E_{G}\right]}\right)\left(1-\frac{\kappa[E]}{\left[E_{G}\right]+\kappa[E]}\right)
\end{aligned}
$$

Thus, we finally obtain the formula of $\dot{p}_{C 2}$ :

$$
\dot{p}_{C 2}=E_{R}\left(\frac{\left\{\dot{p}_{A m}\right\}}{\left[E_{m}\right] V^{1 / 3}}+\frac{\left[\dot{p}_{M 1}\right]}{\left[E_{G}\right]}\right)\left(1-\frac{\kappa[E]}{\left[E_{G}\right]+\kappa[E]}\right)
$$

\section{References}

Alunno-Bruscia, M., Bourlès, Y., Maurer, D., Robert, S., Mazurié, J., Gangnery, A., Goulletquer, P., Pouvreau, S., 2011. A single bio-energetics growth and reproduction model for the oyster Crassostrea gigas in six Atlantic ecosystems. J. Sea Res.

Auby, I., Maurer, D., 2004. Etude de la reproduction de l'huître creuse dans le Bassin d'Arcachon. Tech. Rep. 203 p., IFREMER.

Bacher, C., Gangnery, A., 2006. Use of dynamic energy budget and individual based models to simulate the dynamics of cultivated oyster populations. J. Sea Res. 56, 140-155.

Beninger, P. G., Lucas, A., 1984. Seasonal variations in condition, reproductive activity, and gross biochemical composition of two species of adult clam reared in a common habitat: Tapes decussatus L. (Jeffreys) and Tapes philippinarum (Adams \& Reeve). J. Exp. Mar. Biol. Ecol. 79 (1), 19-37.

Berthelin, C., Kellner, K., Mathieu, M., 2000. Storage metabolism in the Pacific oyster (Crassostrea gigas) in relation to summer mortalities and reproductive cycle (West Coast of France). Comp. Biochem. Physiol. B: Biochem. 125, 359-369.

Beukema, J., Bruin, W., 1979. Calorific values of the soft parts of the tellinid bivalve Macoma balthica (L.) as determined by two methods. J. Exp. Mar. Biol. Ecol. 37 (1), 19-30.

Beukema, J., Bruin, W. D., 1977. Seasonal changes in dry weight and chemical composition of the soft parts of the tellinid bivalve Macoma balthica in the Dutch Wadden Sea. Neth. J. Sea Res. 11 (1), 42-55.

Beukema, J. J., 1997. Caloric values of marine invertebrates with an emphasis on the soft parts of marine bivalves. Oceanogr. Mar. Biol. 35, 387-414.

Bourlès, Y., Alunno-Bruscia, M., Pouvreau, S., Tollu, G., Leguay, D., Arnaud, C., Goulletquer, P., Kooijman, S., 2009 Modelling growth and reproduction of the Pacific oyster Crassostrea gigas: Advances in the oyster-DEB model through application to a coastal pond. J. Sea Res. 62 (2-3), 62-71.

Brody, S., 1945. Bioenergetics and growth. Hafner Press.

Cannuel, R., Beninger, P. G., 2005. Is oyster broodstock feeding always necessary? A study using oocyte quality predictors and validators in Crassostrea gigas. Aquat. Living. Resour. 18, 35-43.

Castaños, C., Pascual, M., Camacho, A. P., 2009. Reproductive biology of the nonnative oyster, Crassostrea gigas (thunberg, 1793), as a key factor for its successful spread along the rocky shores of northern Patagonia, Argentina. J. Shellfish Res. 28 (4), 837-847.

Chavez-Villalba, J., Barret, J., Mingant, C., Cochard, J. C., Le Pennec, M., 2002a. Autumn conditioning of the oyster Crassostrea gigas: a new approach. Aquaculture 210, 171-186.

Chavez-Villalba, J., Pommier, J., Andriamiseza, J., Pouvreau, S., Barret, J., Cochard, J.-C., Le Pennec, M., $2002 b$. Broodstock conditioning of the oyster Crassostrea gigas: origin and temperature effect. Aquaculture 214 (1-4), 115130. 
Comeau, L., Sonier, R., Lanteigne, L., Landry, T., 2010. A novel approach to measuring chlorophyll uptake by cultivated oysters. Aquacult. Eng. 43 (2), 71-77.

Dare, P., Edwards, D., 1975. Seasonal changes in flesh weight and biochemical composition of mussels (Mytilus edulis L.) in the Conwy Estuary, North Wales. J. Exp. Mar. Biol. Ecol. 18 (2), 89-97.

Deslous-Paoli, J.-M., Héral, M., 1988. Biochemical composition and energy value of Crassostrea gigas (Thunberg) cultured in the bay of Marennes-Oléron. Aquat. Living. Resour. 1, 239-249.

Deslous-Paoli, J.-M., Héral, M., Berthomé, J.-P., Razet, D., Garnier, J., 1982. Reproduction naturelle de Crassostrea gigas Thunberg dans le bassin de Marennes-Oléron en 1979 et 1981 : aspects biochimiques et énergétiques. Rev. Trav. Inst. Pêches marit. 45 (4), 319-327.

Diederich, S., Nehls, G., van Beusekom, J. E. E., Reise, K., 2005. Introduced Pacific oysters (Crassostrea gigas) in the northern Wadden Sea: invasion accelerated by warm summers? Helgol. Mar. Res. 59 (2), 97-106.

Emmery, A., Lefebvre, S., Alunno-Bruscia, M., Kooijman, S. A. L. M., 2011. Understanding the dynamics of 13C and $15 \mathrm{~N}$ in soft tissues of the oyster Crassostrea gigas facing environmental fluctuations in the context of Dynamic Energy Budgets (DEBs). J. Sea Res., - .

Fabioux, C., Huvet, A., Le Souchu, P., Le Pennec, M., Pouvreau, S., 2005. Temperature and photoperiod drive Crassostrea gigas reproductive internal clock. Aquaculture 250 (1-2), 458-470.

Fussmann, G., Blasius, B., 2005. Community response to enrichment is highly sensitive to model structure. Biol. Lett. 1, 9-12.

Gentleman, W. C., Neuheimer, A. B., 2008. Functional responses and ecosystem dynamics: how clearance rates explain the influence of satiation, food-limitation and acclimation. J. Plankton Res. 30 (11), $1215-1231$.

Grosberg, R. K., Levitan, D. R., 1992. For adults only? Supply-side ecology and the history of larval biology. Trends Ecol. Evol. 7 (4), 130-133.

Honkoop, J. C., van der Meer, J., Beukema, J. J., Kwast, D., 1998. Does temperature-influenced egg production predict the recruitment in the bivalve Macoma balthica? Mar. Ecol. Prog. Ser. 164, 229-235.

Héral, M., Deslous-Paoli, J., 1983. Valeur énergétique de la chair de l'huîre Crassostrea gigas estimée par mesures microcalorimétriques et par dosages biochimiques. Oceanol. Acta 6 (2), 193-199.

Hughes, T. P., Baird, A. H., Dinsdale, E. A., Moltschaniwskyj, N. A., Pratchett, M. S., Tanner, J. E., Willis, B. L., 2000 Supply-side ecology works both ways: the link between benthic adults, fecundity, and larval recruits. Ecology 81 (8), 2241-2249.

Hyun, K., Pang, I., Klinck, J. M., Choi, K., Lee, J., Powell, E. N., Hofmann, E. E., Bochenek, E. A., 2001. The effect of food composition on Pacific oyster Crassostrea gigas (Thunberg) growth in Korea: a modeling study. Aquaculture 199 (1-2), 41-62.

Kang, C., Park, M., Lee, P., Choi, W., Lee, W., 2000. Seasonal variations in condition, reproductive activity, and biochemical composition of the Pacific oyster, Crassostrea gigas (Thunberg), in suspended culture in two coastal bays of Korea. J. Shellfish Res. 19 (2), 771-778.

Kooijman, S., 2010. Dynamic energy budget theory for metabolic organisation. Cambridge university press.

Kraeuter, J. N., Buckner, S., Powell, E. N., 2005. A note on a spawner-recruit relationship for a heavily exploited bivalve: the case of northern quahogs (hard clams), Mercenaria mercenaria in great south bay New York. J. Shellfish Res. 24 (4), 1043-1052.

Lefebvre, S., Leal, J. C. M., Dubois, S., Orvain, F., Blin, J.-L., Bataillé, M.-P., Ourry, A., Galois, R., 2009. Seasonal dynamics of trophic relationships among co-occurring suspension-feeders in two shellfish culture dominated ecosystems. Estuar. Coast. Shelf Sci. 82 (3), 415-425.

Li, Q., Liu, W., Shirasu, K., Chen, W., Jiang, S., 2006. Reproductive cycle and biochemical composition of the Zhe oyster Crassostrea plicatula Gmelin in an eastern coastal bay of China. Aquaculture 261 (2), 752-759.

Li, Y., Qin, J. G., Li, X., Benkendorff, K., 2009. Spawning-dependent stress response to food deprivation in Pacific oyster Crassostrea gigas. Aquaculture 286 (3-4), 309-317.

Lipcius, R. N., Stockhausen, W. T., 2002. Concurrent decline of the spawning stock, recruitment, larval abundance, and size of the blue crab Callinectes sapidus in Chesapeake Bay. Mar. Ecol. Prog. Ser. 226, 45-61.

MacKenzie, C. L. J., 1996. The eastern oyster: Crassostrea virginica. Maryland Sea grant, Ch. 21, Management of natural populations, p. 734

Mann, R., 1979. Some biochemical and physiological aspects of growth and gametogenesis in Crassostrea gigas and Ostrea edulis grown at sustained elevated temperatures. J. Mar. Biol. Assoc. U.K. 59, 95-110.

Marshall, D. J., Styan, C., McQuaid, C. D., 2009. Marine hard bottom communities. Springer, Ch. 11, Larval Supply and Dispersal, pp. 165-176.

Muranaka, M. S., Lannan, J. E., 1984. Broodstock management of Crassostrea gigas: environmental influences on broodstock conditioning. Aquaculture 39, 217-228.

Navarro, E., Iglesias, J. I. P., Larrañaga, A., 1989. Interannual variation in the reproductive cycle and biochemical composition of the cockle Cerastoderma edule from Mundaca Estuary (Biscay, North Spain). Mar. Biol. 101 (4), $503-511$.

Ojea, J., Pazos, A., Martínez, D., Novoa, S., Sánchez, J., Abad, M., 2004. Seasonal variation in weight and biochemical 
composition of the tissues of Ruditapes decussatus in relation to the gametogenic cycle. Aquaculture 238 (1-4), 451468.

Okumus, I., Stirling, H. P., 1998. Seasonal variations in the meat weight, condition index and biochemical composition of mussels (Mytilus edulis L.) in suspended culture in two Scottish sea lochs. Aquaculture 159 (3-4), $249-261$.

Pecquerie, L., Petitgas, P., Kooijman, S. A., 2009. Modeling fish growth and reproduction in the context of the Dynamic Energy Budget theory to predict environmental impact on anchovy spawning duration. J. Sea Res. 62 (2-3), 93-105.

Poggiale, J., Baklouti, M., Queguiner, B., Kooijman, S., 2010. How far details are important in ecosystem modelling the case of multi-limiting nutrients in phytoplankton-zooplankton interactions. Phil. Trans. Biol. Sci. 365 (1557), 3495-3507.

Pouvreau, S., Bourlès, Y., Lefebvre, S., Alumno-Bruscia, M., 2006. Application of a dynamic energy budget model to the Pacific oyster, Crassostrea gigas, reared under various environmental conditions. J. Sea Res. 56 (2), $156-167$.

Ren, J., Marsden, I., Ross, A., Schiel, D., 2003. Seasonal variation in the reproductive activity and biochemical composition of the Pacific oyster (Crassostrea gigas) from the Marlborough Sounds, New Zealand. New Zeal. J. Mar. Freshwat. Res. 37 (1), 171-182.

Ren, J. S., Ross, A. H., 2001. A dynamic energy budget model of the Pacific oyster Crassostrea gigas. Ecol. Model. $142(1-2), 105-120$.

Ren, J. S., Schiel, D. R., 2008. A dynamic energy budget model: parameterisation and application to the Pacific oyster Crassostrea gigas in New Zealand waters. J. Exp. Mar. Biol. Ecol. 361, 42-48.

Rodhouse, P. G., 1978. Energy transformations by the oyster Ostrea edulis L. in a temperate estuary. J. Exp. Mar. Biol. Ecol. 34 (1), 1-22.

Rosland, R., Strand, Ø., Alunno-Bruscia, M., Bacher, C., Strohmeier, T., 2009. Applying Dynamic Energy Budget (DEB) theory to simulate growth and bio-energetics of blue mussels under low seston conditions. J. Sea Res. 62 (2-3), 49-61.

Royer, J., Seguineau, C., Park, K.-I., Pouvreau, S., Choi, K.-S., Costil, K., 2008. Gametogenetic cycle and reproductive effort assessed by two methods in 3 age classes of Pacific oysters, Crassostrea gigas, reared in Normandy. Aquaculture 277, 313-320.

Ruiz, C., Abad, M., Sedano, F., Garcia-Martin, L. O., Sanchez Lopez, J. L., 1992. Influence of seasonal environmental and biochemeical composition of Crassostrea gigas (Thunberg) in suspended culture in El Grove, Galicia, Spain. J. Exp. Mar. Biol. Ecol. 155, 249-262.

Saraiva, S., van der Meer, J., Kooijman, S. A. L. M., Sousa, T., 2011. DEB parameters estimation for Mytilus edulis. J. Sea Res.

Shafee, M. S., Lucas, A., 1980. Quantitative studies on the reproduction of black scallop, Chlamys varia (L.) from Lanveoc area (Bay of Brest). J. Exp. Mar. Biol. Ecol. 42 (2), 171-186.

Sousa, T., Domingos, T., Kooijman, S., 2008. From empirical patterns to theory: a formal metabolic theory of life. Phil Trans. Biol. Sci. 363 (1502), 2453-2464.

Steele, S., Mulcahy, M. F., 1999. Gametogenesis of the oyster Crassostrea gigas in southern Ireland. J. Mar. Biol. Assoc. U.K. 79 (4), 673-686.

Tran, D., Haberkorn, H., Soudant, P., Ciret, P., Massabuau, J., 2010. Behavioral responses of Crassostrea gigas exposed to the harmful algae Alexandrium minutum. Aquaculture 298 (3-4), 338-345.

Troost, T. A., Wijsman, J. W. M., Saraiva, S., Freitas, V., 2010. Modelling shellfish growth with dynamic energy budget models: an application for cockles and mussels in the Oosterschelde (southwest Netherlands). Phil. Trans. Biol. Sci. 365 (1557), $3567-3577$.

Underwood, A. J., Fairweather, P., 1989. Supply-side ecology and benthic marine assemblages. Trends Ecol. Evol. 4, $16-20$.

van der Veer, H. W., Cardoso, J. F., van der Meer, J., 2006. The estimation of DEB parameters for various Northeast Atlantic bivalve species. J. Sea Res. 56, 107-124.

Whyte, J., Englar, J., Carswell, B., 1990. Biochemical composition and energy reserves in Crassostrea gigas exposed to different levels of nutrition. Aquaculture 90 (2), 157-172.

Workman, C., 1983. Comparisons of energy partitioning in contrasting age-structured populations of the limpet Patella vulgata L. J. Exp. Mar. Biol. Ecol. 68 (1), 81-103.

Wrange, A., Valero, J., Harkestad, L., Strand, Ø., Lindegarth, S., Christensen, H., Dolmer, P., Kristensen, P., Mortensen, S., 2009. Massive settlements of the Pacific oyster, Crassostrea gigas, in Scandinavia. Biol. Invasions 12 (6), 14531458

Zandee, D., Kluytmans, J., Zurburg, W., Pieters, H., 1980. Seasonal variations in biochemical composition of Mytilus edulis with reference to energy metabolism and gametogenesis. Neth. J. Sea Res. 14 (1), 1-29. 